\title{
İ'cazü'l-Kur'an Konusuna Farklı Bir Yaklaşım
}

Enver ARPA

Dr.

A Different Approach To I'caz al-Qur'an. Qur'an is the greatest 'miracle' that was given to our prophet. All the scholars are of the same opinion that nothing similar to the Qur'an can be created. In this 'article' the semantic investigation of this concept, is researched. The opinions given and asserted for this purpose are evaluated and studied one by one. As a result of these evaluations and studies, it is explained why the Qur'an is a miracle.

Key words: I'caz, Mucize, Tehaddi, Muâraza, Sarfe, Belâğat.

\section{Giriş}

Kur'an, Allah tarafından, Cebrail vasıtastyla, insanları hidayete ulaştırmak üzere $\mathrm{Hz}$. Peygambere indirilmiş ve onun en büyük mucizesi kılınmıştır. O, Hz. Peygamberi yalanlayanları, kendisinin benzerini meydana getirmeye davet etmiş ve bunun imkansız olduğunu vurgulayarak meydan okumuştur. Böylece $\mathrm{O}, \mathrm{Hz}$. Peygamberin en somut ve nesnel mucizesi olmuştur. Kur'an'ın inkarcılara yönelttiği bu meydan okumanın sübutu ve inkarcıların acziyeti hususunda herhangi bir tereddüt söz konusu olmamıştır. Ancak onun hangi yönden meydan okuduğu hususunda görüş ayrılıkları vardır. Bir çok konuda olduğu gibi bu meselede de mezhebî ve kişisel eğilimler devreye girmiş ve her kişi/veya mezhep onu kendi ihtisas alanı veya görüşleri doğrultusunda teorize etme uğraşı içerisinde olmuştur. Bu durum, $\mathrm{Hz}$. Peygamberin en somut -belki yegane-mucizesi olan Kur'an'ın bu 
yönünün de tcorik tartışmalar içerisinde kaybolup anlaşılmaz hale gelmesine sebep olmuştur.

Bilindiği gibi Kur'an'ın vahiy oluşu, aklî ve naklî olmak üzere iki delille sübut bulmuştur. Naklî deliller hakkında inkarcılar her zaman bir itirazda bulunmuş ve şüpheler ileri sürebilmişlerdir. Hal böyle iken onun itiraz edilemeyecek yönü olan bu aklî delilinin (i'cazının) teorik tartışmalara boğdurulmadan objektif bir tavırla ortaya çıkarılması son derece önem kazanmaktadır.

Kaynaklarımızda bu konu, umumiyetle genellemeci bir yaklaşımla ele alınmış ve "Kur'an her yönüyle mucizedir" gibi genel hükümler verilerek bunun ispatına çalışılmıştır. Bu tavrı, Kur'an'a duyulan saygı ve onu yüceltme duygusuyla izah etmek mümkündür. Ancak kanaatimizce onun böyle bir yaklaşıma hiç ihtiyacı yoktur. Zira $O$, bizatihi yüce bir kitaptır ve bu yüceliği ispattan varestedir. Onun gerçekten aciz bırakan yönünün tespit edilmesi, istenen neticeyi elde etmeye yeterlidir.

Biz bu incelememizde, bu anlayışla hareket ederek, herhangi bir yüceltici tavır takınmadan, bu konuda yapılmış tartışmaları ele alarak değerlendireceğiz ve Kur'an'ın meydan okuduğu ve inkarcılarını aciz bıraktığı yönünü tespit etmeye çalışacağız. Çalı̧̧mamızın başında i’caz kavramının ortaya ne zaman ve nasıl çıktığını tespit etmemiz ve onun semantik çerçevesini belirlememiz yararlı olacaktır.

\section{I'caz Kavramının Ortaya Çıkışı}

İslam'ın ilk döneminde Müslümanlar, genellikle Kur'an'a pratik/ameli yönden yaklaşmış ve onun teorik yönü üzerinde fazla durmamı̧̧lardır. İslam toplumunun genişlemesi ve İslam'a girenlerin çı̆̆ gibi büyümesiyle birlikte Kur'an'ın pratiğinin yanı sıra teorisine de ihtiyaç duyulmaya başlanmıştır. $\mathrm{Hz}$. Peygamberin vefatından sonra ortaya çıkmış olan problemlerin giderilmesi ve Kur'an'ın daha iyi anlaşılması için onunla ilgili çeşitli meseleler alimler tarafından tasnif edilmeye başlanmıştır.

İ'cazü'l-Kur'an kavramının başlangıçta daha çok Ebû Ubeyde Ma'mer b. el-Müsenna(ö.206h.)'nın Mecazü'l-Kur'an, İbn Kuteybe(ö.276h.)'nin Ğaribü'l-Kur'an ve Müskilü'l-Kur'an'ı gibi dil ve nahiv kitapları ile Taberî(ö.310h.)'nin Camiu'l-Beyan'ı gibi tefsir kitaplarında, söz arasında geçtiğini görüyoruz. Hicri III. Asırdan itibaren bu konu, müstakil eserler halinde te'lif edilmeye başlanmış ve tasnif edilen kitaplar genellikle "Nazmü'l-Kur'an" ismi altında kaleme alınmıştır. Bu konunun bundan sonraki te'lif seyri ise şöyle gelişmiştir: Meşhur Mu'tezilî alim Câhız,(ö.255h.) Nazmü'l-Kur'an ismiyle bir eser kaleme almış, ancak onun bu kitabı bize kadar ulaşmamıştır. Ebübekr Abdullah es-Sicistânî, Ebû Zeyd el-Belhî Ahmed b. Süleyman(ö.322h.) ve çağdaşı Ebübekr Ahmed b. Ali b. 
el-İhşid (ö.326h.) bu asıın ikinci yarısının sonu ile IV. asrın başında aynı isimle eserler te'lif etmişlerdir.'

Hicri IV. Asırda "I' cazü'l-Kur'an" isminin ortaya çıktığını ve sadece bu konuya hasredilmiş eserlerin te'lif edildiğini görüyoruz. Ebü'l-Hasan Ali b. İsa er-Rummanî (ö.386h.)'nin en-Nüket fí i'cazi'l-Kur'an'ı, Ebû Süleyman Hamd b. Muhammed el-Hattabî (ö.388h.)'nin Beyanü i'cazi'l-Kur'an'ı, Ebübekr el-Bakıllânî (ö.403h.)'nin I'cazü'l-Kur'an'ı ve Kadı Abdülcabbar (ö.415h.)'ın Muğnî isimli meşhur kitabının I'cazül-Kur'an cüzü bu dönemde kaleme alınmış eserlerdir. Hicri V. Asırda ise Abdülkahir elCürcânî (ö.47lh) zühur ederek, Delailü'l-i'caz ve er-Risaletu's-şafiye $e^{2}$ isimli kitaplarını te'lif etmiştir.

Bundan sonraki dönemlerde ise alimlerin, daha çok bu konuda yazılmış düşünceleri cem etmekle yetindiklerini müşahede ediyoruz. Celaleddîn esSüyutî (ö.911h)'nin el-Ittkan isimli kitabındaki "Faslu i'cazi'l-Kur'an", Muhammed Abduh(ö.1905)'un Tefsiru'z-zikri'l-hakim isimli tefsirinde son derece veciz ve özet bir şekilde kaleme aldığı "Faslu vücuhi'l-i'caz" gibi çabalar buna örnek gösterilebilir." Abduh'un bu bahsi, veciz olmasına rağmen son derece yararlı bir çalışmadır. Abdülkahir el-Cürcanî'nin Delailü'l-i'caz ve Esrarü'l-belağe isimli kitapları uzun yıllar gözden uzak kalmış ve Abduh'un bu konuda gösterdiği çabalarla yeniden alimlerin ve araştırıcıların ilgisini çekmeye başlamıştır. Abduh, Ezher Üniversitesinde bu iki kitabı okuttuğu gibi özel derslerinde de onlardan bahsederek araştırıcıların dikkatini onlara yöneltmiştir. ${ }^{4}$

Çağımızda bazı ilim adamları, bu konuyu yeniden gündeme taşıyarak müstakil eserler halinde orijinal kitaplar te'lif etmişlerdir. Bu çağda i'caz konusunda kaleme alınan ilk eser, Mustafa Sadık er-Rafiî'nin I'cazü'lKur'an ve'l-belağetu'n-nebeviyye isimli kitabıdır. Ondan sonra Muhammed Abdullah Draz'ın en-Nebeü'l-azîm, Seyyid Kutub'un et-Tasvîrü'l-fennî, Bediüzzaman Said Nursî'nin Işaratü'l-i'caz ve Aişe Abdurrahman'ın elI'cazü'l-beyânî li'l-Kur'an isimli kitapları te'lif edilmiştir.

Bu konuyla yakından ilgilenenlerden biri de Ürdün Üniversitesi Şeriat Fakültesi öğretim üyesi ve benim de hocam olan Prof. Fadl Hasan Abbas'tır. Abbas'ın I'cazü'l-Kur'an, Letâifü'l-Mennan, el-Belâğetu funûnuhâ ve efnânuha gibi kitaplarının yanı sıra çeşitli dergilerde yayımlanmış i'cazla ilgili bir çok araştırması bulunmaktadır.

' Aişe Abdurrahman, Bintu'ş-Şati', el-I'cazü'l-beyanî li'l-Kur'an, Darü'l-Meârif, Misir,1971, s.16.

${ }^{2}$ Bu risalc, Rummanî'nin "en-Nüket fi i'cazi'l-Kur'an"1 ve Hattabî'nin "Beyanü i'cazi'lKur'an"1 ile birlikte "Selasü resâil fi'l-i'caz" ismiyle Mısır'da Darü'l-Meârif tarafindan neşredilmiştir.

${ }^{3}$ Aişe Abdurrahman, a.g.e.s. 34 .

'Abbas Fadl Hasan, I'cazü'l-Kur'an, Amman, 1991. s.93.

s Suat Yıldırım tarafından En Mühim Mesaj Kur'an ismiyle Türkçe'ye tercüme edilmiştir. Biz de incelememizde bu tercümeden yararlandik.

- Abdülmecid Nursî tarafından tercüme cdilen bu kitap, Envar Neşriyat tarafından 1991 yılında yayınlanmıştır. 


\section{Kavramsal Çerçeve}

Kur'an'ın i'cazı hususunda ileri sürülen yönleri incelemeye geçmeden önce bu kavramın semantik yapısı, kavramsal çerçevesi ve onunla ilgili diğer kavramlar üzerinde kısaca durmamız yararlı olacaktır.

\section{a. I'caz}

E'-ce-ze fiilinin mastarı olan i'caz, aciz bırakmak manasına gelir. Bir şeyi meydana getirmekten aciz bırakan şeye ise mucize denir. Mucizenin aslı, mucizdir; sonundaki " $l$ " harfi, mübalağa içindir. Zıddı ise kudrettir. Arapça'da, "Onu aciz bıraktım" demek için: "E'ceztu fulanen" denilmektedir.' Kur'an'ı Kerimde Adem(as)ın oğlunun diliyle şöyle buyurulmaktadır: "Ya veyletâ e a'ceztu en ekûne misle haze'l-ğurab" Yazıklar olsun bana! Şu karga kadar da olamadım mı ki,...?

Mucize, kavram olarak ise, "Peygamberlerin, risâletleri konusunda sadık olduklarını ispatlamak üzere Allah tarafından kendilerine verilen ve benzeri ortaya çıkarılamayan olağanüstü iş veya durum" manasındadır."

$\mathrm{Bu}$ işin olağanüstü oluşu, imkansızlığ 1 anlamında değil, aksine onun, teknik imkanları hâiz olmaları hasebiyle, görünüște imkân dahilinde bulunsa da, insan gücünün fevkinde olmasını ifade etmektedir.

Bu tariften de anlaşıldığı gibi bir hususun mucize sayılabilmesi için bazı şartların tahakkuk etmesi gerekmektedir. Müfessir Kurtubî, tefsirinde bu şartları şöyle sıralamıştır:

1-Allah'tan başka hiç kimse ona güç yetirememeli,

2-Olağanüstü bir iş olmalı,

3-Risâlet sahibi onunla istişhadda bulunmalı,

4-Mucize, benzerini isteyen kişinin amacına uygun bir şekilde gerçekleşmeli,

5-Hiç kimse meydan okunan hususun benzerini muâraza maksadıyla yapamamış olmalı. ${ }^{10}$

Özetle söylemek gerekirse, mucize, Peygamberlere, görevlendirildikleri risalet konusunda sadık oldukların ispatlamak üzere Allah tarafından verilen ve hiç kimsenin benzerini yapamayacağı bazı olağanüstü özellikler veya eylemlerdir.

${ }^{7}$ Bkz. e z-Zebîdî Muhammed Murtedâ, Tacül-ârus, Kuvcyt, 1975, A-ce-ze maddesi. 15/200-201; el-Isfahanî, Rağıb. el-Müfredat, thk. M. Ahmed Halefullah, Mektcbetu Anclo cl-Misriyye, trh. s. 484 .

${ }^{8}$ Maide surcsi: 31 .

${ }^{9}$ Bkz. Cürcaní. Ali b. Muhammed b. Ali, et-Ta'rifat, Darü'l-Kitabi'l-Arabi, 2.baskı. Beyrut, 1992. s.282; Süyutî, Celaleddin, el-itkan fi ulumi'l-Kur'an. thk. Mustafa Diyb el-Buğa. Daru İn Kesir. Dimesk, 2/1001: ez-Zerkanî, Muhammed Abdülazim, Menahilï'l-irfan fi ulumi $\%$-Kur' 'an, Darü'l-Fikr, 2.bask1, 1/73;

"Kurtubî. el-Cami' li ahkami'l-Kur'an, Müessesetü Menahili'l-Kur'an baskısı, 1/70. 


\section{b. Tehaddi (meydan okuma)}

Kur'an ve Hz.Peygamberin, Kur'an'ın Allah kelamı olduğunu söyleyerek, Arapların onun benzerini ortaya çıkaramayacaklarını iddia etmesi ve bunun için meydan okumasıdır. Hz Peygamberin, bu meydan okumayı kendi ifadeleri veya "Ĕ̆ger doğru söylüyorlarsa onun sözlerinin bir benzerini getirsinler" "De ki: And olsun ki, bu Kur'an'ın bir benzerini ortaya koymak üzere insanlar ve cinler bir araya gelseler, birbirlerine destek de verseler, onun benzerini meydana çıkaramazlar." ${ }^{2}$ gibi ayetlerle yapmıs olması arasında bir fark yoktur..$^{13}$

Tehaddi ayetlerini incelediğimizde Kur'an'ın meydan okuma hususunda şu tedrici sıralamayı takip ettiği görülmektedir:

1- Önce belli bir sınırlama koymadan onun benzerini meydana çıkarmaya çağırır:

"Ĕ̆er doğru söylüyorlarsa onun sözlerinin bir benzerini getirsinler"14

2- Eğer onun benzerini getiremiyorsanız, surelerinden 10 tanesinin benzerini getirin:

"Yoksa, "Onu kendisi uydurdu" mu diyorlar? De ki: Ĕ̆er doğru iseniz Allah'tan başka çă̆ırabildiklerinizi yardıma çağırın da siz de onun gibi uydurulmus on sure getirin."15

3- Bunu da yapamiyorsanız, onun bir suresinin benzerini getirin:

"Yoksa onu (Muhammet) uydurdu mu diyorlar? De ki: Ĕger sizler doğru iseniz Allah'tan başka, gücünüzün yettiklerini çağırın da hep beraber onun benzeri bir sure getirin."

4- Eğer bütün bunları yapamıyorsanız onun surelerinden birine benzeyen bir sure getirin.

"Ĕ̆er kulumuza indirdiklerimizden herhangi bir şüpheye düşüyorsanız, haydi onun surelerine benzer bir sure meydana getirin, ĕger iddiantzda doğru iseniz Allah'tan başka şahitlerinizi (yardıncılarınızı) de çağırın." 17

\footnotetext{
11 Tur suresi: 34 .

${ }^{12}$ İsra suresi: 88.

${ }^{13}$ Mahlûf, Abdürrauf, el-Bakıllânî ve kitabühü I'cazü'l-Kur'an, Dan Mektebeti'l-Hayat, Beyrut, 1973, s.20-21.

14 Tur suresi: 34

${ }^{15}$ Hud suresi: 13.

${ }^{16}$ Yunus suresi: 38

${ }^{17}$ Bakara suresi: 23. Ayeti, meallerde verilen manalardan farklı olarak bu şekilde tercüme etmeyi uygun bulduk. Muhammed Abdullah Draz, buradaki inceliğc şu şekilde işaret etmektedir: Bakınız, benzerini istemek mertebesinden, "benzerliğin herhangi bir unsurunu istemek derecesine inmesine dikkat ediniz. Kur'an, onlara adeta söyle diyor: Sizden tam bir nazire istemivorum; bilakis herhangi bir cihetle kayıtl olmaksizin, sadece mutlak (herhangi)bir ફ̧ekilde, benzer bir söz getirmeniz de yeter: tahdidî bir nazire değil, takribî bir nazire de olabilir" Gördüğünüz üzere bu da, mümkün olan tenezzül derecelerinin en alt seviyesidir. Bundan ötürü nüzul sırası bakımından en son gelen meydan okuma çağrısı bu ayet olmuştur. Ayet metninde geçen "min mislihi" tabiri. yani teb'îz edatı olan "min"in kullanılışı, diğer tehaddi ayetlerinde bulunmayıp, yalnız nev'înin en son ayeti olan bu ayctte yet almıştır. Mekke dönemine ait öteki merhalelerde sadece "mislehu" denilmişti.(Bkz. En Mühim Mesaj Kur'an. trc. Suat Yıldırım, Işık yay., Izmir, 1994. s: I01 deki dipnot)
} 
5- Bütün bu aşamalardan sonra Kur'an kendisi son neticeyi koyarak şöyle diyor:

"De ki: And olsun ki, bu Kur'an'ın bir benzerini ortaya koymak üzere insanlar ve cinler bir araya gelseler, birbirlerine destek de verseler, onun benzerini meydana çıkaramazlar."18

\section{c. Muâraza:}

Herhangi birisinin, Kur'an'a benzerlik olması için bir cümle inşa ederek onun, Kur'an'ın ayetlerinin bir benzeri ve aynı özelliklere sahip olduğunu iddia etmesidir. ${ }^{19}$

Bilindiği gibi Hz. Peygamber içinde yaşadığı inkarcı Arap toplumunu Kur'an'ın benzerini meydana getirmeye davet etmiş ve onlar, nesir, şiir ve belâğat gibi tüm teknik donanımlara sahip, şâir, hikmetli sözler söyleyen dâhi ve hâtiplere sahip olmalarına rağmen, Kur'an'a muâraza sayılabilecek hiçbir girişimde bulunmamış; tam aksine Kur'an'ı, "geçmişlerin hikayeleri" ve "sihir" gibi ithamlarla yalanlama cihetine 'gitmiş ve bunun için $\mathrm{Hz}$. Peygamberle savaşma yolunu tercih etmişlerdir. ${ }^{20}$

\section{Kur'an'ın I'caz Yönü}

İslam alimleri, Kur'an'ın Hz. Peygamberi doğrulayan bir mucize olduğu konusunda hemfikirdirler. Ancak onun hangi yönüyle mucize olduğu, insanlara nasıl meydan okuduğu hususunda farklı görüşler ileri sürülmüştür. Biz, burada bu husustaki görüşleri zikrederek bunları değerlendirip, kendi tercihimizi ortaya çıkaracağız.

Süyutî, el-Ittkan fí ulumi'l-Kur'an ${ }^{21}$ isimli kitabında bu konuda alimlerden varid olan görüşleri aşağıdaki şekilde sıralayarak, bazılarının referanslarını vermiş ve bunlar hakkında çeşitli değerlendirmelerde bulunmuştur:

1. Bir grup, tehaddinin zatî sıfatlardan olan Kelam-1 kadim'i talep etmekle vuku bulduğunu, Arapların güç yetiremeyecekleri bir şeyle tehaddiye tabi tutulduklarını iddia etmişlerdir.

2. Nazzam, i'cazın Sarfe ile vuku bulduğunu iddia etmiştir.

3. Diğer bir gruba göre Kur'an'ın i'caz yönü, ondaki gelecekle ilgili haberlerde aranmalıdır. Zira Araplar, böyle bir hususu gerçekleştirmekten acizdirler.

4. Başka bir gruba göre ise onun i'cazı, geçmiş ümmetlerin haberlerinden bahsetmesindedir.

\footnotetext{
${ }^{18}$ İsra suresi: 88.

Bu konuda geniş bilgi için bkz. Süyutî, el-likan fi ulumi'l-Kur'un, 2/1002-1003; Aişe Abdurrahman, el-I'cazül-beyanî li'l-Kur'an. s. 58; Abbas, Fadl Hasan, I'cazü'lKur'an, s.138.

${ }^{19}$ Mahlûf, a.g.e. s. 21.

20) Bkz. Abbas Fadl Hasan, I'cazü'l-Kur'an. s.30; Mahlûf. el-Bakıllânî ve kitabühü I'cazü'l-Kur'an, s.20-21.

${ }^{21}$ Bkz. 2/1005 vd.
} 
5. Bir görüşe göre onun i'cazı, herhangi bir şekilde açığa vurulmadığı halde gönüllerdeki bilgileri açığa çıkarmasındadır.

6. Kadı Ebübekr el-Bakıllânî'ye göre Kur'an'ın i'cazı, metninin sahip olduğu nazm ve te'lifte aranmalıdır. Çünkü $O$, bununla, Arap kelamında bilinen bütün nazımlardan ayrılmaktadır.

7. Fahreddin er-Râzi'ye göre onun i'cazı, fesahatinde, üslubunun eşsizliğinde ve her türlü noksanlıktan salim olmasındadır.

8. ez-Zemlekanî de onun i'caz yönünün, kendisine has te'lifinde olduğunu savunmuştur.

9. İbn Atiyye, onun i'cazının nazmında, manalarının sıhhatinde ve kelimelerindeki fesahatinde olduğunu savunmuş ve bunu cumhuru ulemâya izafe etmiştir.

10.Hazım, Minhacü'l-buleğâ isimli eserinde Kur'an i'cazının, ondaki belâğat ve fesâhatin tüm yönleriyle her asırda üstün kalmasında, hiçbir zaman kimsenin onun benzerini yapamamasında aranması gerektiğini savunmuştur.

11. el-Merakişî, Şerhü'l-Misbah adlı eserinde Kur'an'ın mucizevi yönünün, beyan yönü olduğunu savunmuştur.

12. Rağıb el-Isbahânî, onun i'cazının kendisine has nazmı olduğunu savunmuştur.

13. es-Sekkâkî, onun i'cazının beyan ve meânî yönlerindeki üstünlüğünde olduğunu savunmuştur.

14. el-Hattabî, onun i'cazının her türlü belâğat özelliklerine sahip olmasında yattığını savunmuştur.

15. el-Hattabî'nin ileri sürdüğü diğer bir yön ise, Kur'an'ın kalplerde ve gönüllerde oluşturduğu etkidir.

16. İbn Surâke, onun mu'ciz yönü olarak tüm bu sayılan görüşlere ilaveten, bir de tadad edilmesi güç olan ilimleri havî olmasını ileri sürmüştür.

ez-Zerkeşî, el-Burhan'da zikri geçen tüm bu görüşlere ilaveten Kur'an'ın şu yönlerden de mu'ciz olduğunu savunmuştur.

17.-İnanmış olsun olmasın dinleyen herkesin kalbine korku salması, eskimemesi,

-Okuyan ve dinleyen kişi için daima yepyeni olarak kalması ve

-Metnindeki son derece veciz kullanıma rağmen, zevk verici bir yapıda olması. Zira, beşer kelamının, bu derece veciz kullanımla birlikte, zevk verici olması genellikle zordur.

-Son kitap kılınması, başka bir kitaba ihtiyaç bırakmaması, diğer kitapların açıklama hususunda, bazen ona müracaat etme ihtiyacı içerisinde bulunması.

21. er-Rummanî, onun i'cazının, inkarcıların, yapılan tüm tehaddilere rağmen, şiddetle ihtiyaç duydukları halde ona muâraza etmemesi, belâğat, gelecekle ilgili haberler vermesi, olağan dişı ve her türlü mucizeden üstün olması yönleriyle gerçckleştiğini savunmuştur. 
22. Kadı İyad ise Kur'an'ın, veciz ibareler, belâğat, benzersiz üslûb, gaybdan haber verme ve geçmişlerin hikayelerini anlatma yönüyle mu'ciz olduğunu savunmuştur.

İ'caz konusunda alimlerden vârid olan görüşler özetle bu şekildedir. Bizim bu görüşleri burada zikretmemizin amacı, bu sorunun tarihî seyri hakkında bilgiler vermek ve bu konunun nasıl teorik tartışmalar içerisinde anlaşılamaz bir hal aldığını ortaya çıkarmaktır. Bu görüşlerin çoğunu isabetli olmaktan uzak kılan husus, onların tehaddi ayetlerinde belirtilen çerçevenin dışına çıkmış olmalarıdır. Sözgelimi, ilk görüşte tehaddinin, Kelam-ı kadim'le vuku bulduğu ileri sürülmüştür. Kelam-ı kadim, somut bir obje değil ki, onun üzerinde durulsun ve benzeri meydana getirilebilsin.! Tehaddinin son aşamasında, onun sadece bir suresinin benzerinin ortaya çıkarılması istenmiş; bu sure için herhangi bir özellik belirtilmemiştir. Dolayısıyla bu sure, Kur'an'ın en küçük suresi olan Kevser suresi de olabilir. $O$ halde i'caz yönü bu en küçük sure de dahil olmak üzere, Kur'an'ın bütün surelerinin sahip olduğu bir husus olmalıdır. Oysa bu konuda konuşanlar, genellikle bu hususu gözden uzak tutmuş, Kur'an's methetme gayreti içerisinde, onun her yönüyle mu'ciz olduğunu ileri sürmüşlerdir. Kur'an'ın her yönüyle mu'ciz bir kitap olduğuna bir itiraz ileri sürmek kabil değildir. Ancak onun her suresinin bütün bu hususları kapsadığını ileri sürmek isabetli değildir. Örneğin bazı surelerde gaybî haberlerden, gelecekle ilgili haberlerden ve ilmi gelişmelerden hiç bahsedilmemiştir. Binaenaleyh i'caz yönü bütün sureler için geçerli olan bir husus olmalıdır.

Biz şimdi bu görüşleri toplu bir değerlendirmeye tabi tutarak Kur'an'ın bahsettiği bu tahaddiye uygun düşüp düşmediklerini inceleyecek ve sonunda tercih edeceğimiz yön üzerinde duracağız.

Yukarıda zikrettiğimiz görüşleri incelediğimizde çoğunun birbiriyle içiçe olduğunu, yalnız başına bir yön olarak zikredilmeye elverişli olmadıklarını görürüz. Bu görüşleri kategorize etmek istediğimizde ise netice itibariyle şu ana yönlerin ortaya çıktığını görüyoruz:

1.Sarfe yönüyle i'caz,

2.Gaybî haberler verme yönüyle i'caz. 3. 4. ve 5. görüşler bu başlık kapsamina girmektedir.

3.Beyân sanatı yönüyle i'caz. 6. 7. 8. 9. 10. 11. 12. 13. 14. 19. ve 22. numaralı görüşler ise bu maddeye girmektedir.

4.Psikolojik etkileme yönüyle i'caz. Bu, el-Hattabi'nin ikinci olarak zikrettiği görüş̧ür.

5.Ilmi muhteva yönüyle i'caz. Bu görüş ise, İbn Surâke'ye aittir.

Bu görüşlere ilave olarak çağımız alimleri tarafından ileri sürülen iki görüş daha vardır:

6.Teşrî yönüyle i'caz,

7.Sayısal sisteme uygunluk yönüyle i'caz.

Şimdi bu görüşleri teker teker ele alıp, onların i'caz için uygun bir görüş olup olmadıklarına bakalım. 


\subsection{Sarfe}

Genellikle Mu'tezilî alimler tarafından kabul gören Sarfe'nin ilk sahibi olarak kabul edilen Nazzam, ${ }^{22}$ onu şöyle ifade etmektedir: Kur'an'ın i'cazı Sarfe ile vuku bulmuştur. Allah, Arapları imkanları dahilinde olduğu halde, akıllarını selbederek, Kur'an'ın dışından, harici bir sebep ile onun benzerini meydana çıkarmaktan alıkoymuştur. ${ }^{23}$

Sarfe'nin en önemli savunucularından biri olan er-Rummanî ise Sarfeyi, “insan muhayyilesinin Kur'an'ın benzerini meydana getirmekten alıkonması" şeklinde tarif etmektedir. ${ }^{24}$

Nazzam ve er-Rummanî'nin dışında, Nazzam'ın meşhur talebesi Câhız, İbn Sinan el-Hafâcî, İbn Hazm ez-Zahin̂, eş-Şerif el-Murtedâ gibi alimler de Kur'an'ın Sarfe cihetiyle mu'ciz olduğunu savunmuşlardır.

Alimler, bu görüşte geçen, "Allah onları alıkoydu" tabiriyle neyin kastedildiği hususunda farklı görüşler ileri sürmüşlerdir. Bu konuda üç ihtimal zikredilmiştir:

a. Araplar şiddetle muhtaç oldukları halde, Allah onlardan muâraza etme düşüncesini almıştır.

b. Allah, onlardan, muârazada bulunmaları için gerekli olan ilimleri çekip almıştır.

c. Allah, onları güçleri yeter durumda iken, Kur'an'a muâraza etmekten

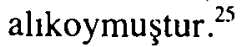

Adı geçen ihtimallerden hangisi kastedilmiş olursa olsún, Kur'an'ın bu tarz bir alıkoymayla mu'ciz kılındığını iddia etmek kanaatimizce doğru bir yaklaşım değildir. Allah'ın, insanların ellerini kollarını bağlayıp onlara, "haydi bu Kur'an'ın benzerini siz de meydana getirin" demesi mantıkla bağdaşmaz. Bu durum, meydan okumanın değil aksine acziyetin bir ifadesi olur. Zira bir insandan gücü çekildiği zaman o insan ölü mesabesine düşer. Ondan bir şey talep etmek -hele bunu bir meydan okuma şeklinde yapmaknormal bir durum olamaz. ${ }^{26}$ Halbuki ayeti kerimede, "De ki: And olsun ki, bu Kur'an'ın bir benzerini ortayà koymak üzere insänlar ve cinler bir araya gelseler, birbirlerine destek de verseler, onun benzerini meydana çıkaramazlar."27 buyurulmuştur. Kudreti ellerinden alınmış insanların bir araya gelmesi bir güç oluşturamaz. Dolayısıyla böyle bir meydan okumayı Allah (c.c) için düşünmek caiz değildir.

\footnotetext{
${ }^{22}$ Abas, Fadl Hasan, I'cazü'l-Kur'an, s.99; el-Bedrî, Ali, Hakaik ve ebatîl, Darü'lKitabi'l-Cahir, l.bask1, 1982, s.145.

${ }^{23}$ Suyutî, el-Itkan, 2/1005; el-Bedrí, a.g.e. aynı yer.

${ }^{24}$ Bkz. en-Nüket fí i'cazi'l-Kur'an (Selasü resail fi'l-i'caz içinde) thk. Ahmed Halefullah, Muhammed Zeğlul Selam, Darü'l-Mearif, Mısır, 1 baskı, s. 101.

${ }^{25}$ ez-Zerkanî, Menahilü'l-irfan fi ulumi'l-Kur'an, 2/414; el-Imañ, Ali, Havle i'cazi'lKur'an, Kahire, 1962, s.82.

${ }^{26}$ ez-Zerkeşî , el-Bürhan fi ulumi'l-Kur'an, Darü'l-Fikr, 1 baskı, 1988, 2/105.

${ }^{27}$ Isra suresi: 88.
} 
Kur'an'ın Sarfe cihetiyle mu'ciz olduğunu savunanların bu tezlerine gösterebildikleri en önemli -hatta yegâne- benzerlik, Allah'ın, Zekeriyya(as)'dan -bir ayet olması amacıyla- üç günlüğüne konuşma kabiliyetini almasıdır. Bu durumun, Kur'an tehaddisiyle bir benzerliği ve alakası yoktur. Zira Zekeriyya'(as)ın hadisesinde kendisine bu durumun bir mucize olarak Allah tarafından musallat kılındığı söylenmiş ve bu ilân edilmiştir. Kur'an tehaddisinde ise böyle bir şey söz konusu değildir. Burada mu'ciz olan Allahu Teâla değil, onun indirmiş olduğu Kur'an'dır. Kaldı ki, İmam Bakıllanî'nin de vurguladığı gibi, ${ }^{28}$ böyle bir durum, tehaddinin tabiatına da aykırıdır. Eğer Cenâbı Allah, böyle bir tavır takınmış olsaydı Kur'an'ı, basit bir metin olarak inzal buyurup, "buyurun gücünüz yetiyorsa, siz de bu basit metin gibi, bir metin ortaya çıkarın" demesi gerekirdi. Halbuki Kur'an, en üstün belâğ̂̀ özelliklerle indirilmiş ve insanların, asla onun özelliklerine sahip bir metin ortaya çıkaramayacakları ilân edilmiştir.

Kur'an'ın Sarfe cihetiyle mu'ciz olduğu görüşü, daha önce işaret ettiğimiz gibi Mutezile mezhebine mensup alimler dısında pek kabul görmemiş, ez-Zemlekânî, ${ }^{29}$ el- Bakıllanî, ${ }^{30}$ el-Hattabî, ${ }^{31}$ Abdülkahir elCürcanî, ${ }^{32}$ İbn Teymiyye, ${ }^{33}$ Zerkeşî $^{34}$ ve Suyutî ${ }^{35}$ gibi bu konuyla ilgilenen meşhur alimler tarafından şiddetle reddedilmiştir.

Çăğımıda bu konuyu ele alan bütün alimler de bu görüşe şiddetle karşı çıkmış̧ır. Sözgelimi Mustafa Sadık er-Rafiî, bu sözün, ancak mektep çocuklarından çıkabileceğini iddia ederek onu, istihzaî bir tavırla değerlendirmeye almışıı. ${ }^{36}$ Muhammed Abdullah Draz ise bu sözün batıl olduğunu belirterek şöyle der:

"Kur'an'ın benzerini yapma hususundaki aczlerine sebep, imkanları dahilinde olduğu halde sırf karşılaştıkları bir engel olmuş olsayd, bu aczleri, ancak işe teşebbüs ettikten ve kendilerini denedikten sonra anlaşılması gerekirdi. Zira insan, mesela kalkmak ve oturmak gibi eskiden yapabildiği bir işe gücünün kalıp kalmadığını ancak tecrübe ile anlayabilir. Biz onların bu tecrübeye girişmediklerini pek iyi biliyoruz:"37

\footnotetext{
${ }^{28} \mathrm{Bkz}$. Mahlüf, Abdürrauf, el-Bakıllanî ve kitabühü i'cazü'l-Kur'an. s.166.

${ }^{29} \mathrm{Bkz}$. el-Bürhanü'l-kâşif a'n i'cazi'l-Kur'an, Matbaatü'l-Á'ni, Bağdat.trh. s.53 vd.

${ }^{30}$ Bkz. Mahlüf, a.g.e. s.166 vd.

${ }^{31}$ Bkz. Beyanü i'cazi'l-Kur'an, (Selasü resail fi'l-i'caz içinde) s.20 vd.

${ }^{32} \mathrm{Bkz}$. er-Risaletü's-şafiye (Selasü resuil fi'l-i'caz içinde) $s .133 \mathrm{vd}$.

${ }^{37}$ Bkz. Ibn Teymiyye, et-Tefsiru'l-kebir, derleme ve thk. Abdurrahman Umayra, Darü'lKütübi'l-İlmiyye, Beyrut.trh. 2/157.

${ }^{34}$ Bkz. cz-Zerkeşî. el-Bürhan fi ulumi'l-Kur'an, 2/105.

${ }^{35}$ Bkz. Süyutî. el-Itkun fi ulumi 'l-Kur'an, s. 2/1005-1006.

3o Bkz. er-Rafiî, I'cazü'l-Kur'an ve'l-belağetü'n-nebeviyye. Darü'l-Kitabi'l-Arabî. Beyrut, 1990, s.154

${ }^{37}$ Draz Muhammed Abdullah, En Mühim Mesaj Kur'an, s.106.
} 
Said-i Nursî de İşaratü'l-i'caz isimli kitabında, aynı gerekçeyle bu düşünceyi reddetmiştir. ${ }^{38}$

Kur'an'ın harici bir sebeple değil, gerçekten aciz kalındı̆̆ı için benzerinin ortaya çıkarılamadığına, bu saydığımız gerekçelere ilaveten şu hususları da delil göstermemiz mümkündür:

1. Araplar, Zekeriyya(as)ın konuşmaktan alıkonulması gibi, Kur'an'ın benzerini meydana getirmekten alıkonulmuş değildirler. Zira Zekeriyya(as)'dan bahseden ayeti kerimede şöyle denilmektedir: "Zekeriyya: Rabbim! Bana bir ayet ver. Allah, senin ayetin, üç gün süreyle insanlarla konuşamamandır, dedi." 39 Burada Zekeriyya(as)a verilen bu ayetin bizzat Allah tarafından meydana getirildiği açıkça ifade edilmiştir. Eğer Kur'an'ın benzerini meydana getirme hususunda inkarcılar gerçekten Allah tarafından engellenmiş olsaydı, bu durum açıç̧a anlaşılır ve onlar bunu ifade ederlerdi. Oysa durum bunun tam tersine olmuştur. Ayeti kerimede bu konuda şöyle buyurulmuştur: "Onlara ayetlerimiz okunduğu zaman şöyle derler: Duyduk, eğer dileseydik biz de bunun benzerini söylerdik. Çünkü bu, geçmişlerin hikayelerinden başka bir şey değildir." ${ }^{, 40}$

2.İnkarcıların tchaddiden önceki halleriyle sonraki halleri arasında, Zekeriyya(as)'da olduğu gibi, bir değişiklik söz konusu olmamıştır. Dolayısıyla onların güçlerinin ellerinden alındığı tezi doğru olamaz.

3. Bu iddiaya göre Arap belâğati, Kur'an'ın nüzulünden sonra bir duraklama devrine girmiş, insanların güçleri ellerinden alındı ̆̆ için sürekli zayıf kalmaya mahkum bırakılmıştır. Oysa bu doğru değildir. Arap dili her dönemde belâğati ve beyan üslubuyla seçkin diller arasındaki yerini muhafaza etmiş, hatta ön sıralarda yer almıştır.

4. Kur'an, daima ayetlerinin üzerinde düşünülmesini emretmektedir. Onun insanların güç ve kabiliyetlerini çekip aldığı iddiası bu emirleriyle çelişmektedir.

5. Günümüzde inkarcıların bu tehaddiye karşılık vermeye ne kadar ihtiyaç hissettikleri malumdur. Eğer Kur'an'ın i'cazı, o dönemde Arapların bundan alıkonulmasıyla olup imkan dahilinde bulunan bir durum olsayd, günümüzdeki inkarcıların bu tehaddiye mutlaka cevap vermeye çalışmaları gerekirdi ${ }^{41}$

\footnotetext{
${ }^{38}$ Bkz. Işaratü'l-i'caz, Envar Neşriyat, 1991. İstanbul, s. 123.

${ }^{39}$ Meryem surcsi: 10

"Enfal suresi: 31 .

${ }^{41}$ Bu konuda daha geniş bilgi ve açıklamalar için bkz. el-Cürcanî, Abdülkahir, erRisaletü's-safiye,(Selasü resail fi'l-i'caz) s.133; el-Hattabî, Beyanü i'cazi'l-Kur'an. (Selasü resail fíl-i'caz) s.20; ez-Zerkcsî, el-Bürhan fi ulumi'l-Kur'an, 2/105; czZemlekânî, el-Bürhanül-kaşif a'n i'cazi'l-Kur'an.s.54; Ibn Teymiyye, et-Tefsirǘlkebir, 2/157; ez-Zerkanî. Me'nahilü'l-irfan, 2/415 vd.; Abdürrauf Mahlüf. el-Bakıllanî ve hirabühü i'cazü'l-Kur'an, s.166.
} 


\subsection{Gaybi haberlerden bahsetme yönüyle i'caz}

Kur'an'da geçen gaybi haberler, geçmiş milletlerin hikayeleri ve gelecekle ilgili durumlar olmak üzere, iki türlüdür:

\section{2 a. Geçmiş ümmetlerin hikayeleri}

Kur'an'ın bu yönüyle mu'ciz olduğunu savunanlara göre $\mathrm{Hz}$. Muhammed, ümmî bir insand1, okuma yazması yoktu ve eski ümmetlerin hallerini bilen bir ortamda da yetişmemişti.

"Resulüm! Bunlar, bizim sana vahiy yoluyla bildirmekte olduğumuz. gayb haberlerindendir. İçlerinden hangisi Meryem'i himayesine alacak diye kur'a çekmek üzere kalemlerini atarlarken sen onların yanında değildin. Onlar bu yüzden çekişirken de yanlarında değildin." "İşte bu Yusuf kıssast gayb haberlerindendir. Onu sana vahyediyoruz. Onlar hile yaparak işlerine karar verdikleri zaman sen onların yanında değildin ki onu bilesin." 43 "Resulüm! İşte bunlar sana vahyettiğimiz gayb haberlerindendir. Bundan önce onlart ne sen biliyordun ne de kavmin."

Ayeti kerimelerde de işaret edildiği gibi onlar, bu tür bilgilere sahip değildi. Kur'an, onların bilmediği bu hususları bildirerek kendisinin Allah katından olduğunu ispatlamıştır. Kur'an'da geçen bu haberlerin bazıları, diğer semavi kitaplarda da bulunmamaktadır. Dolayısıyla Allah'tan başkasının onları bilmesi ve anlatması mümkün değildir. ${ }^{45}$ Kur'an, Hz. Peygamberin bütün bunlara rağmen Kur'an'1 uydurduğunu iddia edenlere, "eger onun bir insan tarafindan uydurulduğunu iddia ediyorsanız, o halde buyurun sizde böyle gaybdan haber veren bir sure indirin de görelim" diyerek meydan okumuştur.

\section{$4.2 \mathrm{~b}$. Gelecekle ilgili haberler}

Kur'an, geçmiş ümmetlerin hayatlarını anlattığı gibi, bazen de gelecekle ilgili bilgiler vermektedir. Bu çeşit bilgilerin insanlar tarafından bilinmesi imkansızdır. Onun bu çeşit gaybî haberler vermesi Allah katından olduğunun en büyük kanıtıdır. Kur'an, kendisinin Allah kelamı olduğu hususunda şüphe ileri sürenlere, "buyrun siz de gelecekten, gerçeğe mutabık haberler veren bir sure indirin de görelim" demiştir.

Kur'an'ın gaybî haberler yönünden mu'ciz olduğunu savunanların verdikleri en meşhur örnek, Fars İmparatorluğu'nun uğrayacağı hezimetten bahseden ayetlerdir. Muhammed Ebû Zehra bu konuda şöyle demektedir:

"Hiç kimsenin bilemeyeceği, gelecekle ilgili haberler türünden olup, sadece Kur'an'ın bahsetmiş olduğu haberler pek çoktur. Bunlardan biri şudur: Hz Peygamber Mekke'de yaşıyordu ve onunla Şam arasındaki mesafe oldukça uzun idi. Kur'an ona,

\footnotetext{
${ }^{42}$ Al-i İmrân suresi: 44.

${ }^{43}$ Yusuf suresi: 102.

${ }^{44}$ Hûd suresi: 49.

${ }^{45}$ Ebû Zehra, el-Mü'cizetü'l-kübra: el-Kur'an, Darï'l-Fikri'l-Arabî, 1970, s.340.
} 
Farsların büyük bir hezimete uğrayacağını bildirmek için şöyle demiştir: "Elif.Lam.Mim. Rumlar En Yakın bölgede yenilgiye uğradılar. Ancak onlar, bu yenilgilerinden sonra birkaç yıl içinde galip geleceklerdir." 46

Gerçektende birkaç yıl sonra İranlılar, Rumlarla tekrar savaşa tutuşmuş ve büyük bir yenilgiye uğratılmışlardır. Hz. Peygamber bu olayı ne yaşamış ne de müşahede etmişti. Kur'an'da buna benzer olaylar geçmekte olup, hepsi de gerçekleşmiş bulunmaktadır. Bunlar, ancak Allah tarafindan bildirilen haberlerdir. İnsanların onları tahminen ortaya atması imkan dahilinde değildir." ${ }^{, 47}$

Kur'an'ın gaybî haberler yönünden mu'ciz olduğunu savunan ilk kişi muhtemelen Mu'tezilî alim Nazzâm'dır. Ancak Nazzâm, Kur'an'ın bu yönüyle mu'ciz bir kitap olduğunu kabul etse de inkarcıların, Sarfe sebebiyle bundan aciz kaldıklarını ileri sürmüş̧ür. ${ }^{48}$ Nazzâm'dan sonra bu yönü ileri süren kişi ise yine Mu'tezili bir alim olan er-Rummanî'dir. Ancak o da, Kur'an'ın daha çok gelecekle ilgili haberler verme yönünden mu'ciz olduğunu savunmuştur. ${ }^{49}$ Rummanî 'nin çağdaşı olan el-Hattabî ise, bu yönü kabul etmekle birlikte, bunun her surede bulunmadığını dolayısıyla yalnız başına i'caz için yeterli olamayacağını ileri sürmüşşür. ${ }^{50}$ Hicri 4 . asrın sonuyla 5. asrın başında yaşayan el-Bakıllanî de, bu yönü diğer bazı yönlerle birlikte bir bütün olarak değerlendirerek, mu'ciz yön olarak kabul etmiştir. ${ }^{5 !}$

Görüldüğu gibi bu yönü ileri süren alimler, genellikle onu diğer yönlerle birlikte icaz denkleminin bir parçası olarak kabul etmişlerdir. Bu durum daha önce işaret ettiğimiz genellemeci tavrın tabii bir sonucu olup, Kur'an'ın İ'caz cihetiyle doğrudan bir alakası yoktur. Zira Kur'an, bir ayırım gözetmeden, inkarcilardan Kur'an'in herhangi bir suresinin benzerini meydana getirmeyi talep etmiştir. Kur'an'ın bütün surelerinde bahsi geçen bu özellikleri görmekse kabil değildir. Dolayısıyla Kur'an i'cazının bu yönde aranması tehaddiyle uyum arzetmemektedir.

Çağdaş araştırmacılardan bu konuyla ilgilenenler de, genellikle bu hususun, i'caz için yeterli bir unsur olamayacağını kabul etmişlerdir. Sözgelimi Üstad Mahmud Şakir, Kur'an'ın icazının, gelecekte tasdik edilecek olan gaybî haberlerde değil, nazm ve tertibindeki gizemde ve güzellikte aranması gerektiğini savunmuştur. ${ }^{52}$ Kur'an, lafızlarıyla, terkiplerindeki uyumuyla, vermek istediği manalara uygun ibareleriyle en

\footnotetext{
${ }^{46}$ Rum suresi: $1-5$.

${ }^{47}$ el-Mü'cizetül-kübrâ: el-Kur'an, s. 341.

${ }^{48}$ Bkz. Abbas, Fadl Hasan, I'cazü'l-Kur'an, s.38.

${ }^{49}$ Rummanî'nin verdiği misaller için bkz. en-Nüket fî vücühi'l-i'caz, (Selasü resail fi'l$i^{\prime}$ caz içinde) s.101-102.

${ }^{50}$ Bk7. Beyanü i'cazi'l-Kur'an, (Selasü resail fi'l-i'caz içinde) s.21.

${ }^{51} B k 7$. Mahlüf, el-Bakıllanî ve kitabühü i'cazü'l-Kur'an, s.170.

s2 A.g.c. s.172
} 
üstün beyan derecesine ulaşmıştır. Onun bu özelliği hiçbir zaman gözden uzak tutulmamalıdır.

\section{3. Beyan sanatı yönüyle I'caz}

Kur'an'ı Kerim, şiir olsun nesir olsun, diğer metinlerden, vermek istediği manayı ifade etmek üzere seçtiği kelimeler ve bu kelimelerden oluşturduğu te'lifteki üstün başarısıyla temayüz etmektedir. Başlangıcından günümüze kadar, Kur'an'ın metin ve hitabette Arap üslubundan daha farklı bir üsluba, cümlelerinin son derece etkileyici bir yapıya, ifade için başvurduğu tasvirler hususunda eşsiz bir ayrıcalığa sahip bulunduğu, ibaresi ile medlulü arasında mükemmel bir uygunluk sağladığı hususunda bütün dilbilimciler ve müfessirler hemfikirdir. Kur'an'la ilgilenenler, sürekli olarak Onun sahip olduğu bu özellikler üzerinde düşünmeye ve esrarını çözmeye gayret sarf etmişlerdir. Kur'an kendisi de bu yönüne dikkat çekmiş ve onun Allah dışında bir kişi tarafından meydana getirilme imkanının bulunmadığını şöyle vurgulamıştır: "Kur'an'ı düşünmezler mi? Ĕger Allah'tan başkası tarafindan gelmiş olsaydı onda bir sürü çelişki bulacaklardı!" $\$ 3$

Kur'an'ın, genel olarak belağî özellikler yönüyle mu'ciz olduğu hususu alimlerin pek çoğu tarafından kabul görmüş olmakla birlikte, her biri onu farklı bir isimle ifade etmiş bulunmaktadır. Sözgelimi Kadı Abdülcabbar' in "fesahat" olarak ileri sürdüğü bu özelliği, el-Hattabî ve Abdülkahir elCürcanî, "nazm" olarak ifade etmiştir. er-Rummanî̀nin "belâğat" diye ifade ettiği hususu, bir başkası "nazm" olarak; Hattabi'nin, "nazm" dediğini ise bir başkası "belâğat" olarak ifade etmiştir. Ancak bu konuda ileri sürülen ve bizim "beyan sanatı" olarak isimlendirdiğimiz bu görüşlerin tümü, belâğat, fesahat ve nazm olmak üzere üç başlık altında değerlendirilebilir. Dolayısıyla biz burada bu üç husus hakkında bilgi vermekle yetineceğiz.

\section{3 a. Belâğat ve Fesâhat}

Cümle yapısıyla alakalı olan belâğat ve fesahat kavramları, i'caz konusundaki çalışmaların daima odak noktasında yer almışlardır. Lisanü'lArab'da: Belî̆ kişi, güzel sözlü ve fasih kişi olup, kalbinde bulunan şeyin künhünü kendi ibaresiyle açıklayandır, denilmektedir. ${ }^{54}$ Ancak ad geçen bu luğat kitabı gibi bazı kaynaklarda bu kavramlar, birbirinin müteradifi olarak verilmekle birlikte, fesahat, daha çok kelimelerle; belâğat ise daha çok terkiplerin yapısıla ilgilidir. ${ }^{55} \mathrm{Bu}$ kelimelerin semantik analizini yaptığımızda onların, öncelikle, "istenilen manayı, bıktırıcı uzatmalardan ve manayı bozacak kadar veciz olmaktan uzak, garabet ve zorlamalara girişmeden en uygun kelimelerle veren güzel kelam" manasında kullanıldığını görürüz. er-Rummanî , bu hususa şu sözlerle işaret etmektedir:

\footnotetext{
${ }^{53}$ Nisa suresi: 42 .

${ }^{44}$ İbn Manzur, Lisanü'l-Arab, Beyrut. 1956. Be-la-ğa-maddesi, 8/420.

${ }^{s 5}$ Bkz. el-Hafacî, Íbn Sinan, Strrü'l-fesâhe, thk. Ali Fevde, I.baskı, Mektebetü'l-Hancî, 1932.s. 60. Abbas. Fadl Hasan, el-Belağetü fünunüha ve efnanüha (Illmü'l-meânî) Darü’l-Furkan, 2.baskı, Amman.1989, s.53-54.
} 
"Belâğat, sadece manayı anlaşılır bir şekilde ifade etmekten ibaret değildir. Çünkü bazen hiç beliğ olmayan bir kişinin de sözü anlaşılabilir. Belâğat, aynı zamanda 'lafzın istenilen manaya uygun seçimi'nden ibaret de değildir. Zira lafız, bazen zorlama ve kerih te olsa manayı tahakkuk etmeye yeterli gelebilir. Dolayısıyla belâğat ancak, mananın, kalbe en güzel lafızlarla ulaşmasını temin etmektir." ${ }^{56}$

Kur'an'in belâğat yönüyle bir mucize olduğunu sistematik bir şekilde dile getiren ve bununla meşhur olan ilk kişi er-Rummanî'dir. Her ne kadar Kur'an'in i'caz yönü olarak yedi hususu zikretmiş olsa da, er-Rummanî, bunlardan en fazla belâğat yönü üzerinde durmuştur. en -Nüket fî Vücûhi'l$i^{\prime} \mathrm{caz}$ isimli risalesinde bu yedi yönü de sıralarken, ${ }^{57}$ özcllikle belâğat üzerinde geniş̧e durmuş, diğer hususları, incelemesinin sonuna bırakarak kısaca değinmiştir.

er-Rummani, Belâğati üç kısma ayırmaktadır:

-En üstün düzeydeki belâğat,

-En alt düzeydeki belâğat,

-Bu ikisinin ortasındaki belâğat.

er-Rummani'ye göre bu en üst düzeyde olan belâğat mu'cizdir ve buna da sadece Kur'an sahiptir. Ona göre Kur'an'ın belâğati şu on bölümden oluşmakta olup bu hususlardaki üstünlüğüule insanları aciz bırakmıştır:

-Îcaz: Az lafızla geniş bir manayı ifade etmek,

-Teşbih: Benzetmelerle manayı izah etmek,

-İstiare: Kelimeyi konulduğu mananın dışında kullanmak,

-Telâum: Verilmek istenen manaya uygun kelimeleri seçmek,

-Fevâsıl: Ayet sonlarının manaya uygun şekilde bağlanması,

-Tecânus: Kelimeler arasındaki bağlantı ve ses yakınlığı,

-Tasrif: Kelimenin birden fazla manaya gelmesi,

-Tadmîn: Kelamın açıkça zikredilmeyen hususları da kapsaması

-Mubâlağa: Oluşturulan cümlenin, verilmek istenen manayı tam olarak ifade etmesi,

-Beyan: Verilmek istenen mesajın en uygun formatlarla ifade edilmesidir.

er-Rummanî'nin çağdaşıı olan el-Hattabî, belâğatı, Kur'an'ın mu'ciz yönü olarak kabul etmekle birlikte, bu hususta konuşanların bunun için belirli esaslar koymadıklarını, bunu sadece gönle hoş geldiği için kabul ettiklerini iddia ederek, buna karşı çıkar. Ona göre Kur'an'ı diğer metinlerden ayıran özellik, onun, anlatılan konuya ve muhataba göre söz irad etmesinde yatmaktadır. Kur'an, farklı kültürel ve sosyal yapıdaki insanlara hitap etmiş ve çeşitli konuları gündeme getirmiştir. Bununla birlikte $O$, her konuyu kendisine uygun düşecek en iyi anlatımla dile getirmiş ve muha-

\footnotetext{
${ }^{56}$ en-Nüket fi vücûhi'l-i'caz (Selasü resail fi'l-i'caz,içinde) s.69-70

${ }^{57}$ Bkz. en Nüket fi vücuhi'l-i'caz. (Selasü resail fi'l-i'caz içindc), s.69
} 
tapların dikkat ve hayretini celp etmiştir. Kur'an'ın dişındaki herhangi bir kelamınsa bunu başarması imkan dahilinde değildir. ${ }^{58}$

Kadı Abdülcabbar ise bu hususu fesahat ismi altında ele alarak, fasih kelam için iki şart ileri sürmüştür:

-Lafzın istenilen manayı en iyi dile getiren bir kelime olması,

-Oluşturulan cümlenin düzenli cümle olması.

Ona göre kelime veciz, ancak cümle düşük ise, bu fasih sayılamaz. Fesahat, sadece tercih edilen kelimelerle değil, aksine seçilen bu veciz kelimelerin birbirine en güzel şekilde bağlanmasıyla ortaya çıkar. Bunun için de şu üç hususa dikkat edilmelidir:

-Tercih edilen kelimenin verilmek istenen anlama uygunluğu,

-Bu kelimenin i'rab yönünden uygun olarak kullanılması,

-Takdim te'hir, ta'rif tenkir (ma'rife-nekire) vb. yönlerden en uygun sayılabilecek bir mevkide kullanılması. ${ }^{59}$

Belâğat yönüyle ilgili olarak orijinal sayllabilecek görüşler bunlardır. Dolayısıyla biz bu konuda sözü daha fazla uzatmadan nazm hakkında da biraz bilgi vermek istiyoruz.

\section{$4.3 \mathrm{~b}$. Nazm}

Kur'an'ın İnsanları hayrette bırakan diğer bir yönü ise, Arapların daha önce hiç alı§̧ı olmadıkları bir cümle yapısına (nazm) sahip olmasıdır. O, ne nesir türü bir metin, ne de bilinen şiirsel bir metindir. Onun kendine has bir yapısı vardır.

$\mathrm{N}-\mathrm{z}-\mathrm{m}$ maddesini ve türevlerini incelediğimizde nazm kelimesinin, Araplar tarafından daha çok te'lif ve müteradifi olan kelimelere karşıllık olarak kullanıldığını görürüz. Sözgelimi, Lisanü'l-Arab ${ }^{, 60}$ ve el-Kamusü'lmuhit ${ }^{\phi l}$ gibi luğat kitaplarında nazm kelimesi, te'lif kelimesinin müteradifi olarak verilmiştir. Mu'cemü'l-vasît'te ise bu madde altında şu bilgiler verilmektedir:

-Nezame el-eşyâe: Eşyayı düzenledi, birbirine kattı,

-İntezeme eş-şey'u: Düzenlendi, koordine edildi,

-en-Nizam: Düzen ve tertip demektir. ${ }^{62}$

Bu verilerden hareketle Kur'an nazmın, "Mushaf'ın ifade yönünden sahip olduğu format" şeklinde tarif etmemiz mümkündür.

Kur'an' in nazmı ile mu'ciz olduğu düşüncesi, alimlerin çoğunluğu tarafından müspet karşılanmıştır. Bazıları bu husus üzerinde ehemmiyetle durmuş, Kur'an'ın bu yönünü açı̆̆a çıkarmaya büyük gayret sarf etmiştir. Kur'an'ın nazmıla mu'ciz olduğunu savunan ilk kişi muhtemelen meşhur

${ }^{88} \mathrm{Bkz}$. Beyanü i'cazi'l-Kur'an, (Selasü resail fi'l-i'caz içinde), s.22-23; Abbas Fadl Hasan, $I$ 'cazü̈'l-Kur'an, s.48 vd.

${ }^{59}$ Abbas Fadl Hasan, a.g.e, s.48.

${ }^{60} 12 / 578$.

${ }^{61}$ el-Fîyruzâbâdî, Muhammed b. Ya'kub, el-Kamusü'l-mühît, Müessesetü'r-Risale, 2.bask1, 1987, s.1500.

${ }^{62}$ Bkz. el-Mü'cemü'l-vasit, Çağrı yay. İstanbul, 1992, N-z-m. Maddesi, s.933. 
Mutezilî alim Câhız'dır. Ancak onun bu konuda te'lif etmiş olduğu kitabı maalesef günümüze kadar ulaşmamıştır.

Nazm fikrinin üstadı sayılan Abdülkahir el-Cürcanî ise, bu konudaki çalışmalarıyla temayüz etmiş kişi olup, kendisinden sonra gelen alimlere büyük oranda öncülük etmiştir. Her ne kadar Ebû Hilal el-Askeri, erRummanî, el-Hattabî, İmam Bakıllanî, Abdülcabbar el-Hemedânî gibi alimler bu hususu, Cürcanî'den önce dile getirmişler ise de, Cürcanî'nin bu konudaki düşünceleri daha fazla şöhret bulmuştur. Biz de bu yüzden burada sadece onun düşüncelerini vermekle yetineceğiz.

Abdülkahir'e göre bir kelamın, mütekellimin maksadını ifade edebilmesi ve muhataplar nezdinde hüsnü kabul görebilmesi için üç şu unsuru bünyesinde barındırması gerekir: Lafız, mana ve nazm. Lafız, meramımızı ifade etmek için kullandığımız harf ve sözcüklerdir. Mana ise, içimizde bulundurduğumuz ve muhatabın anlaması için ifade etmek istediğimiz manalardır. Buna göre lafızlar, vermek istediğimiz mananın formatlarıdır. Mana ise bu formatlarla ifade edilen şeylerdir. Sözgelimi bir çiçek gördügümüzde hoşumuza gidiyorsa, içimizde oluşan bu durum, manayı ifade etmektedir. Bunu dışımızdakilerin de bilmesini istediğimiz zaman onu harfler ve kelimelerle ifade ederiz. İşte burada lafızla mana arasında bir ilişki söz konusu olmaktadır. Belagat alimlerinden kimisi bu ilişkide lafzın konumunu önemsemiş, kimisi ise manaya daha fazla önem atfetmiştir. Abdülkahir, bu iki unsurun dışında, üçüncü bir unsur olan nazmı ön plana taşıyarak, onun önemini ısrarla vurgulamıştır.

Ona göre nazm, mana için en uygun formatın seçilmesidir. Bunu şu şekilde izah etmemiz mümkündür: Kelimeler ve cümlelerle konuşmak istediğimiz zaman seçeceğimiz kelimelerin ve kuracağımız cümlelerin, düzenli makul ve nahiv kaidelerine uygun olmaları gerekir. Bu, nazmın ilk şartıdır. İkinci şart ise, kuracağımız bu cümlelerin içimizdeki manayı tam olarak yansıtabilecek bir dikkatle kurulmasıdır ki, bu, birinci şarttan daha önemlidir. Bu tertip, o kadar dikkatli ve seçilerek olmalıdır ki, istenilen manayı eksiksiz bir şekilde ifade etmeli, gereğinden fazla sıkıcı ve uzun da olmamalıdır. Böylece Abdülkahir'in ileri sürdügü bu nazm nazariyesinin iki aşamadan meydana geldiği görüyoruz:

-Manaların içimizde(nefsimizde)tertip edilmesi,

-Bunun ifade edilmesi için uygun lafızların seçilmesi.

$\mathrm{Bu}$ açıklamalardan sonra Abdülkahir' in nazm nazariyesini şu şekilde ifade etmemiz mümkündür: Nazm, iç dünyada(nefiste) oluşan manalara uygun lafızların, cümlelerde gereken şekilde tertip edilmesidir. ${ }^{63}$

Abdülkahir, bu nazariyesini ayetlere tatbik etmek üzere takdim-te'hir, hazf-zikir, ta'rif-tenkir, te'kid, haberin farklı kalıplarla verilişi, kasr, fasl-vasl gibi çeşitli belağ̂́ özelliklerle ilgili misaller vererek açıklamalarda bulunmuştur. Bizim burada bu hususlar üzerinde durmamız incelememizin

${ }^{63}$ Bu açıklamaları, Fadl Hasan Abbas'ın I'cazü'l-Kur'an isimli kitabından özetleycrek aldım. Daha geniş bilgi için bkz.. a.g.e, s.65 vd. 
sınırlarını aşacaktır. Ancak onun bu tatbikatından bir misal vererek bu konuyu noktalamamız yararlı olacaktır. Abdülkahir, ilk maddede zikretmiş olduğumuz takdim-te'hir konusunda, Enbiya suresi 62. ayetini misal vermektedir. Ayette şöyle buyurulmuştur: "Kâlû e ente fea'lte hâzâ bi âlihetinâ ya İbrahim" Ayette "ente" lafzı, fiilden önce verilmiştir (takdim edilmiştir). Halbuki normal kullanımda fiilin başa alınması ve "e fea'lte hâzâ" denilmesi gerekiyordu. Bunun sırrı şudur: Cümle kurulurken şüphe edilen şey hangisi ise o, başa alınır. Şüphe, isim konusunda ise isim başa alınır; fiil konusunda ise fiil takdim edilir. Burada şüphe duyulan husus, putların kırılması değil, bunun kim tarafından yapıldığıdır. Zira putların kırıldığı ortadadır. Onlar, bu şekilde cümle kurarak bu işi İbrahim'e yıkmak, ona bunu itiraf ettirmek niyetindedirler. Ayet, onların içlerinde oluşmuş bulunan manaya uygun bir terkiple varit olmuştur. ${ }^{64}$

\subsection{Psikolojik etkileme yönüyle i'caz}

Kur'an'ın en önemli özelliklerinden biri de, dinleyenlerini büyük bir etki altında bırakması, tabir caizse insanı adeta mest etmesidir. Onu dinleyen kişi derin bir manevi deryaya dalıp gitmekte, dış dünyadan soyutlanarak manevi hazzın zirvesine ulaşmaktadır.

"Allah, sözün en güzelini, hepsi aynı güzellikte olan bıkılmadan tekrar tekrar okunan bir kitap olarak indirdi. Rablerinden korkanlarin, bu kitabin etkisinden tüyleri ürperir, derken hem bedenleri ve hem de gönülleri Allah'in zikrine isıntp yumuşar." ${ }^{\circ 5}$

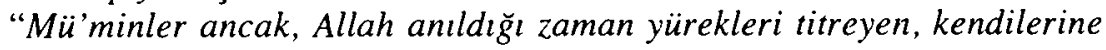
Allah'ın ayetleri okunduğunda imanlarını artıran ve yalnız Rablerine dayanip güvenen kimselerdir." 66

Kur'an'ın bu tesiri sadece inananlarla sınırlı kalmamıştır. O, inansın veya inanmasın kendisine kulak veren herkesi derinden etkilemiş, beyninde fırtınalar koparmıştır. Sözgelimi, ahiretteki cezalandırmadan bahsettiğinde, onu dinleyen her kişi, onun etkisinde kalmış, bu korkuyu gönlünün derinliklerinde hissetmiştir. Cennetten bahsettiğinde ise dinleyenlerini o yüce makamların hayaliyle mest etmiştir. Nice İslam düşmanı, Hz.Peygamberi öldürme düşüncesiyle meşgul iken, dinlediği Kur'an sayesinde bu fikrinden vazgeçmiş ve kendisini Kur'an'ın bu büyüleyici etkisine terk etmiştir. Onun insan üzerinde meydana getirmiş olduğu bu etkinin benzerini başka herhangi bir kelamda bulmak kabil görünmemektedir. Insanlar, bu büyüleyici etki sayesinde akın akın Islam'a girmişlerdir. Sözgelimi, Ebû Zerr' in kardeşi Üneys'in İslam'a giriş hadisesi... (Ebû Zerr, şöyle anlatıyor): Kardeşim Üneys, Mekke'ye gitmem gerekiyor, dedi ve yola çıktı. Döndüğünde, "Neler oldu, neden geciktin?" diye sordum. Şöyle cevap verdi: Bir adamla karşılaştım, kendisinin bir peygamber olduğunu

\footnotetext{
${ }^{\infty}$ Abdülkahir'in bu tatbikatları hakkında daha fazla bilgi için bkz. a.g.e. s.75 vd.

is Zümer suresi:23.

${ }^{\text {क力 }}$ Enfâl suresi: 2.
} 
söylüyordu. "İnsanlar onun hakkında neler söylüyor?" diye sordum. Onun, bir şair, sihirbaz ve kahin olduğunu söylüyorlar, dedi. Ebû Zerr: Kardeşim bir şair idi ve şöyle sürdürdü: Vallahi onun sözünü, şiir kafiyesine uyguladım asla uygun düşmedi; pek çok kahinin sözünü duymuştum, onlara da hiç benzemiyordu. Yemin ederim ki, o doğru söyleyenlerdendi ve onlar yalanciların ta kendileriydiler. ${ }^{67}$

Kur'an'1 kabul etmeyenler de onun bu büyüleyici etkisini itiraf etmek zorunda kalmışlardır. Utbe b. Rebîa, Hz. Peygamberin azılı düşmanlarından biriydi. Kureyş' in düşüncelerini anlatmak üzere $\mathrm{Hz}$. Peygambere gidip şöyle dedi:

"Ey kardeşimin oğlu! Bildiğgin gibi sen bizden birisin. Kavmine yeni bir din icat ettin, onunla kavminin birliğini bozdun, aralarındaki sevgiyi saygıyı yok ettin, ümitlerini suya düşürdün ve ecdadımızı ayıpladın..."

Utbe, biraz sonra Hz. Peygamberden Fussilet suresinin başından "..Ĕ̆ger yüz çevirirlerse de ki, sizi Ad ve Semud kavminin başına gelen kasırgaya karşı uyarıyorum." ellerini arkasına bağlayarak bitkin bir hale düşmüş, rengi sararmış, ayetlerin, onun beyninde oluşturduğu fırtınayla yıldırım çarpmışa dönmüş; yorgun ve bitkin bir halde arkadaşlarının yanına gelerek şöyle demiştir:

“Ey Kureyş Topluluğu! Bu defa beni dinleyiniz! Ondan sonra dilerseniz bana isyan ediniz. Bu adamı düşündükleriyle baş başa bırakınız. Eğer Araplar, ona bir zarar verirlerse, istediğiniz, gerçekleşmiş olacak. Yok eğer galip gelirse unutmayınız ki, O sizdendir, Onun mülkü sizin de olur ve siz böylece insanların en mutlularından olursunuz. Ondan öyle bir söz işittim ki, o gerçekten ne şiir ne sihir ve ne de bir kehanettir."

Kur'an'ın manevî-ruhî etki yönüyle mucizeliğini savunan ilk kişi, muhtemelen Eş'arî kelamcısı el-Hattabî'dir. Hattabî, kendisinden önce insanların bu yönü fark edemediklerini söylemektedir. ${ }^{70}$ Hattabî'den sonra bu yönün başkaları tarafından dile getirildiğine dair kaynaklarda bir bilgiye rastlanamamaktadır.Çağımızda Muhammed Ferîd Vecdî gibi bazı ilim adamları i'cazın bu cihetini oldukça önemseyerek en önemli i'caz yönü olarak ileri sürmüşlerdir. ${ }^{71}$

Kur'an'ın inanılmaz derecede manevi bir etki oluşturduğu hususu şüphe götürmez bir gerçektir. Ancak unutulmaması gereken husus şudur ki, bu etki, ancak Kur'an'ın sahip olduğu anlatım güzelliğinden kaynaklanmaktadır.

\footnotetext{
${ }^{67}$ el-Cürcânî, Abdülkahir. er-Risalctü'ş-şafiye,(Selâsü resâil fíl-i'caz İçinde) s.114.

${ }^{\text {sx }}$ Fussilet suresi: 1-13.

${ }^{69}$ cl-Cürcânî, Abdülkahir, a.g.e., s. 113.

${ }^{70}$ Beyanü i'cazi'l-Kur'an, (Selasü resail fi'l-i'caz içinde) s. 113.

${ }^{71}$ Abbas, Fadl Hasan, l'cazü'l-Kur'an, s.348.
} 
Eğer Kur'an, bu derece mükemmel bir metin ve manaya sahip olmasaydı bu etki meydana gelmeyecekti. Dolayısıyla bu yönü yalnız başına i'caz için yeterli bir yön olarak görmek isabetli olamaz. Çünkü onun varlığı, başka sebeplerin varlı̆̆ına bağhıdır.

\section{5. İlmi muhteva yönüyle i'caz}

Kur'an'ı Kerimde kâinat, gökyüzü, yeryüzü, yıldızlar, bulutlar, yağmur, şimşek çakması, gece ve gündüzün birbirini takibi, insanın yaratılışı, ceset, ruh ve beden yönünden gelişimi, nebatat, hayvanat, haşarat, dağlar, ağaçlar, nehirler ve denizler gibi pek çok konudan bahseden ayetler bulunmaktadır. Kur'an'ın indiği dönemde insanlığın bu hususlarda bilgisi ya hiç yoktu ya da çok sınırlıydı. Kur'an verdiği bu bilgilerle, insanları hayrette bırakıyor, onları etkisi altına alıyordu. Bilim geliştikçe Kur'an'ın bu yönü daha iyi anlaşılmış̧ır.

Kur'an'ın ilmi muhteva yönüyle mu'ciz olduğunu savunanlara göre Kur'an, inkarcılara, "Eğer onun Allah katından olmadığını, bir insan tarafından ortaya atıldığını savunuyorsanız, siz de bir insansınız, buyurun siz de bu şekilde ilmi muhtevaya sahip olan bir sure getirin", diyerek meydan okumuştur.

Kur'an'ın zengin bir ilmî muhtevaya sahip olduğu hususu, alimler arasında ihtilaflı bir konudur. İmam Şatıbî'nin öncülüğünü yaptığı gruba göre Kur'an' 1 , eldeki ilmî verilerle tefsir etmek ve onun bu yönlerle mu'ciz olduğunu savunmak yanlıştır. Çünkü:

-Hz.Peygamberin indiği topluluk, ümmî bir topluluk idi ve onlara indirilen şeriat de onların düzeyine göre indirilmişti,

-Kur'an'ın indiği ümmî Arap toplumu, sadece Kur'an'da geçen, yıldızlara ait bilgiler, tecrübelerle elde edilen bazı tıbbî meseleler ile ahlakî bazı konularda bilgi sahibi idi ve Kur'an, onlara bu hususlarda tehaddide bulunmuştur.

-İslam ümmeti, sonradan bir çok bilgiye ulaşmıştır ki, sahabe bu konularda bilgi sahibi değillerdi. Kur'an, Araplara tehaddide bulunduğu zaman onlara, ancak bildikleri hususlarda meydan okumuştur; bilmedikleri şeyleri onlardan istemesi makul değildir. ${ }^{72}$

İmam Şatıbî, bu konuyu nasıl reddetmiş ve menfi tutum takınanlara öncü olmuşsa ${ }^{73}$ Müfessir Fahreddin er-Râzî de, bunu savunanların öncüsü sayılabilir. Razî, tefsirini bu tip ilmi verilerle doldurmuş ve bunu şiddetle savunmuştur. Şöyle demektedir:

"Bazı cahil ve ahmaklar şöyle diyebilir: Sen Kur'an'ın tefsirini alışılmışın dışında yıldız ve hey'et ilmiyle doldurdun. Bu miskine şöyle cevap verilir: Eğer sen Allah'ın kitabını hakkıyla teemmül etseydin, dediklerinin ne kadar yanlış olduğunu anlardın. Zira

${ }^{72}$ eş-Şatıbî, el-Muvafakât fî usûli'ş-şerîa, şrh. Muhammed Abdullah Draz, Matbaatü'şŞarki'l-Ednâ, s. 69 vd.

${ }^{73}$ Abbas, Fadl Hasan, I'cazü'l-Kur'an, s.251. 
Allah, kitabını, yeryüzü, gökyüzü, gece gündüzün birbirini takibi, $ı$ şık, karanlık, yıldızlar, güneş, ve ayın durumu gibi konulardaki kudret, ilim ve hikmet üzerine yaptığı istidlâllerle doldurmuş ve bunu bir çok surede zikrederek, zaman zaman tekrar etmiştir. Ĕ̆er bunlar hakkında incelemelerde bulunmak caiz olmasaydı, Allah, kitabını bunlarla doldurmazdı." 74

Alimlerin ekseriyeti, Kur'an'ın ilmî verilerle tefsir edilmesinde bir sakınca görmemişlerdir. İmam Şatıbî'nin menfi tavır takınmasını da anlayışla karşılamak lazım. Zira onun yaşadığı dönemde bilimsel gelişmeler, günümüzde olduğu kadar net ve kesin değildi. Şatıbî, muhtemelen bu konuyu istismar eden, duyduğu her veriyi Kur'an ayetlerine uygulamaya çalışan kişilere duyduğu tepki üzerine bu derece sert bir tavır takınmıştır. Gerçekten de bazen bu hususta aşırı derecede ileri giden, doğruluğu tam olarak ispatlanamamış bilimsel verileri, Kur'anî veriler diye sunan kişilerle karşılaşmaktayız. Bu, son derece sakıncalı bir durumdur. Çünkü bütün bilimsel bulgular doğruluğu kesin olan bulgular değildir ve bunları, Kur'an'ın sunduğu veriler olarak kabul ettiğimizde, bunlar hakkında sonradan meydana gelebilecek yanılmalar, Kur'an'a ihale edilmiş olur. Ancak doğruluğu kesin olarak ispatlanmış, değişiklik ihtimali asla söz konusu olmayan bilimsel veriler ışığında ayetleri anlamaya çalışmanın ise hiçbir sakıncasının bulunmadığına inandığımızı ifade ederek tekrar asıl konumuza dönelim.

Kur'an'ın kapsadığı ilmî bilgiler yönünden mu'ciz olduğu görüşü de kanaatimizce sağlıklı bir yaklaşım değildir. Bu durum, tehaddinin tabiatına aykırıdır. Zira Kur'an, Arapları, Kur'an'ın benzerini meydana getirmeye davet ettiği zaman, onlar hangi yönden bir benzerlik oluşturmaya davet edildiklerini gayet iyi biliyorlardı. İmam Şatıbî'nin de işaret ettiği gibi, o dönemlerde Kur'an'ın dile getirdiği bazı hususlar hemen hemen hiç bilinmiyordu. İnsanların hiçbir malumata sahip olmadıkları bir hususta tehaddiye tabi tutulması kanaatimizce uygun değildir. Kaldı ki, Kur'an'ın bütün sureleri, ilmi konulardan bahsetmemektedir. Kur'an, inkarcılara onun herhangi bir suresinin benzerini meydana getirmeyi önermiştir. Bu tehaddi, bütün sureler için geçerlidir. Binaenaleyh bu yön de Kur'an'ın bahsettiği tehaddi için uygun bir yön değildir.

\subsection{Teşrî için koyduğu hükümler yönüyle i'caz}

Araştırmamızın başında işaret ettiğimiz gibi bu yön, Fadl Hasan Abbas, ${ }^{75}$ Menna' el-Kattan, ${ }^{76}$ Muhammed Ebû Zehra ${ }^{77}$ ve Muhammed İsmail İbrahim $^{78}$ gibi asrımızdaki bazı ilim adamları tarafından dile getirilmiştir.

\footnotetext{
${ }^{74}$ Razî, et-Tefsirü'l-kebîr, Daru Ihyai't-Türasi'l-Arabî, 3.baskı, 14/121.

${ }^{75}$ I'cazü'l-Kur'an, s. 295.

${ }^{76}$ Mebahis fî ulûmi'l-Kur'an, Müessesetü'r-Risale, Beyrut, trh, s. 275 vd.

${ }^{\pi}$ el-Mü'cizetül-kübrâ, s. 91-92.

${ }^{78}$ el-Kur'an ve i'cazühü't-teşrî́, Darü'l-Fikri'l-Arabî baskısı.
} 
Bunlara göre Kur'an, toplumsal ve ferdi hayat için koyduğu prensiplerle, diğer beşeri nizamlardan fevkalade üstün ve adil bir sistem ortaya koymuştur. Onun ceza hukuku, aile hukuku, miras hukuku, kadın, yetim ve komşu hukuku gibi alanlarda koyduğu prensipler, insanlığı mutlu edebilecek en güzel prensiplerdir. Onun bu prensipleri, insanın maddi ve manevi yönleri için gerekli olan tüm hususları göz önünde bulundurmuştur. Muhammed İsmail şöyle demektedir:

"İslamî teşrî ile beşerî sistemler arasında tarafsız bir mukayese yaptığımız zaman şu hususlar dikkatimizi çekmektedir:

-İslamî teşñ, gerekli bütün usûl, kaide ve ilkelere sahip olup hak ve yükümlülü̈kleri belirlemiştir.

-İslâmî teşrî ilahî kaynaklıdır. Onun hükümlerini, gözünden hiçbir şey kaçmayan, yanılmayan, doğrudan başka bir şey emir buyurmayan, kötülüklerden başka bir şey nehy etmeyen hakimler hakimi olan Allah Teala vazetmiştir.

-Allah, genel kaideleri koymuş, cüz'iyyatı terk etmiştir ki, alimler ve fakihler maslahatı gerektiren konularda içtihadda bulunsun.

-İslamî teşrî, mü'minin imanıyla uygunluk arzeden bir yapıya sahiptir.

-İslamî teşrî, en geniş manasıyla insanın bütün ilişkilerini, Allah'la olan ilişkisini, nefsiyle olan ilişkisini ve başkalarıyla olan ilişkisini düzenlemiştir.

Beşerî düzenlemelere gelince, onlar yanılması mümkün olan, adalet ve aynı zamanda zulümle hükmetmesi mümkün olan insan ürünleridir. İnsan zihni ne kadar üstün olsa da, onun bilgi ve idrak alanı sınırlıdır. Onun, bütün her şeyi bilgi yönünden kuşatması mümkün değildir. Onun ulaşabileceği ilim, ancak beşerî talim yoluyla elde edeceği bilgiyle sinırlıdır." ${ }^{79}$

Fadl Abbas ise, Kur'an'ın inanç ve düşünce özgürlüğüu, muamelât, kişi hukuku ve ceza hukuku alanında koyduğu prensiplerle diğer beşerî düzenlemelerden üstün bir nizam vazettiğini vurgulayarak buna misaller vermektedir. ${ }^{80}$

$\mathrm{Bu}$ yön üzerinde duranlar, onu, yalnız başına yeterli bir yön olarak ileri sürmemişlerdir. Onlara göre Kur'an, inkarcilara bu alanda da tehaddide bulunmuş ve onların bu güzellikte ilkelere sahip bir kitap meydana getiremeyeceklerini iddia etmiştir. ${ }^{81} \mathrm{Bu}$ anlayış, daha önce bahsettiğimiz genellemeci yaklaşımın tipik bir örneğidir. Bu yaklaşım, Kur'an'a birden fazla mu'ciz yön bulunca, onun kıymetini daha fazla yücelteceğini düşünmektedir. Oysa Kur'an'ın yüceltilmeye ihtiyacı yoktur; O, bir Allah kelamıdır ve bu durum, onun yüceliği için yeterlidir. Onun koyduğu hü-

\footnotetext{
${ }^{79}$ el-Kur'an ve i'caziihii' 't-leşrî̀.s.34-35.

*'Bkz. I'cazï'l-Kur'an, s.326.

${ }^{81}$ Bkz. a.g.e. aynı yer.
} 
kümlerin, en yüce prensipler olduğu hususunu ifade etmeye bile gerek yoktur. Ancak onun bu yönüyle tehaddide bulunduğu hususu ihtiyatla karşılanmalıdır. Zira bu tip prensipler vazeden ayetlerin sayısı beş yüz dolayındadır ve bunlar da belirli surelerde varit olmuştur. Tehaddi ise daha önce birkaç defa işaret ettiğimiz gibi bütün sureler için söz konusu olmuştur. Dolayısıyla Kur'an, Araplara meydan okurken kanaatimizce bundan başka bir hususu gözetlemiştir.

\subsection{Sayısal sisteme uygunluk yönüyle i'caz iddiası}

Son yıllarda bir de Kur'an'ın, bünyesinde barındırdığı sayısal bir sisteme uygunluk yönüyle mu'ciz olduğu iddiası ortaya atılmıştır. Bu iddiayı ortaya atanları iki grupta değerlendirmek mümkündür:

Birinci grup, konuyu iyi niyetle ele alan bazı ilim adamlarıdır. Ancak bunların çabaları apaçık zorlamalarla doludur ${ }^{82}$ Zaten böyle bir iddia, İslam uleması tarafından şimdiye kadar hiçbir şekilde söz konusu yapılmamışıır. Bunu ortaya atanlar onu, İmam Bakıllanî ve müfessir ez-Zcmahşeri'ye dayandırmak istemiş̧lerdir. Oysa bu iddianın, bu iki değerli alimle hiçbir alakası yoktur. Fadl Abbas, bu hususa şu gerekçelerle itiraz etmektedir:

Bu iki değerli alimin sözlerini düşünen kişi, onların söyledikleriyle, sonradan ona yüklenilen mana arasindaki belirgin farkı rahatlıkla görecektir. İmam Bakıllânî, i'caz yönlerinden bahsederken, Kur'an'ın gaybî haberlerden bahsetmesi, eski ümmetlerin halini anlatması, Kur'an'ın benzersiz nazmı ve belâğati olmak üzere üç yön zikretmiştir. Bakıllânî, bu son yön için on özellik sıralamış, dokuzuncu maddede, sure başlarında verilen harflerin sayısının on dört olduğunu ve bunların her türlü sıfatları havi olduğunu, onlarda mehmûs ve mechûr ${ }^{83}$ harfler başta olmak üzere bütün harflerin bulunduğunu söylemiştir.

ez-Zemahşerî ise, Bakara suresinin başındaki (Elif Lâm Mîm)hakkında konuşurken alimlerin bunlar hakkındaki görüşlerini zikrederek, bunların tehaddi ve tenbih için getirildikleri görüşünü tercih etmiştir. Zemahşen̂ bu bağlamda, Bakıllânî'nin kendisinden önce söylediklerini tafsilatlı olarak anlatmıştır.

O halde bu iki alim, bu konuyu, Kur'an'ın beyanından ve belâğatından bahsederken dile getirmişlerdir. Onlar, uzaktan yakından sayısal benzerlik konusuna değinmemişlerdir. ${ }^{84}$

Ikinci grup ise, bu konuyu art niyetle dile getiren Bahaiye, Babiye, Kadıyaniye gibi sapık ve İslam düşmanı fırkalardır. Bunlar, İslam'ı dı̧̧ardan

\footnotetext{
${ }^{82}$ Misal olarak bkz. Abdürrezak Nevfel'in Mü'cizetü'l-erkam ve't-terkîm ismli kitabı...

${ }^{83}$ Mahrecinden çıkarırken sesi gizli ve hafif çıkararak telafuz edilen harflere mehmus, harfi hareke ile mahrecinden çıarıp okurken boşluk bırakmadan nefesin hepsini veya ekserisini hapsederek sesin aşikare çıkarıldı̆̆ı harflere isc mechur harfler denilir. Bu harfler hakkında daha fazla bilgi için bkz. Uñü, Demirhan, Kur'an-ı Kerim'in Tecvidi, Şamil yay. Ankara, trh. s. 50.

${ }^{84}$ Bkz. Abbas, Fadl Hasan, I' cazü'l-Kur'an, s.351-352.
} 
yok edemeyeceklerini anlayınca, İslam'a girmiş gibi görünerek onu savunduklarını iddia etmeye başlamışlardır. ${ }^{85}$

Onların son yıllardaki liderleri Amerika'da yaşayan ve yakın zamanlarda öldürülen Muhammed Reşat Halife'dir. Reşat, bu kitabını sayısal benzerlikler kurgusuyla doldurmuş ve 19 rakamı üzerinde yoğunlaşmıştır. Ona göre Kur'an'ın sırrı ve nazmının üstünlüğü, bu 19 rakamındaki benzerlikte yatmaktadır. 19 sayısı, Müddessir suresinde varid olmuştur. Besmele de bu sırra binaen 19 rakamından teşekkül etmektedir. Yine ilk ayeti besmele olan Fatiha suresinin tamamı, Müddessir suresinin "levvaheten li'l-beşer, aleyha tisa'te aşer" ayetlerinden sonra nazil olmuştur. Yani Fatiha suresinin bir ayeti olan besmele, Hz. Peygambere "Aleyha tisa'te aşere" ayetinden sonra indirilmiştir. Çünkü besmele 19 (Tisa'ate Aşere)sayısından teşekkül etmiştir. Reşat'a göre buradaki hakikat, yalnız başına Kur'an'ın bir insan ürünü olmadığına yeterli bir delildir. Hüseyin Nacî, bu iddianın kökeninin Babiye fırkasından geldiğini söylemektedir. ${ }^{86}$

Kur'an'ın buna benzer bulmaca türü şeylerle mu'ciz olduğunu savunmak aklı selimle bağdaşmamaktadır. Böyle bir şey, tehaddiye muhatap olan kişiler tarafından hiçbir şekilde hatırdan geçirilmemiştir. Sözgelimi, Kur'an surelerinin benzerini meydana getireceğini iddia edip denemeye girişen Müseylemetü'l-Kezzab, oluşturduğu ve komik hale düştüğü şu cümlelerinde böyle bir hususu asla göz önünde bulundurmamıştır:

"Ya Dafde' binte dafdaeyni nakkî kem tunekkîyne, le'l-mae tukeddiriyne, vele'ş-şaribe temneîyne, re'suki fî'l-mai ve zenbuki fî't-tîyn"

“İna a'teynake'l-cevahir, fesalli li rabbike ve cahir"

"Ve'tahinati tahnen, ve'l-acinati a'cnen, ve'l-habizati hubzen"

Öte yandan, Reşat'ın bu iddiası, bir çok yönden yanlışlıklar içermektedir. Örneğin bu düşüncesine dayanak yaptığı 'besmelenin 19 rakamdan oluştuğu iddiası' dahi doğru değildir. Zira besmele, 20, eğer Rahman kelimesindeki Elif'i de sayarsak tam 21 harften oluşmaktadır. Reşat'ın fiziksel gerçek olarak ileri sürdüğü hususlarda bu kurgusunu formüle etmek için pek çok hileye başvurduğu görülmektedir. Sözgelimi, 3 nolu fiziksel gerçek diye ileri sürdüğü tezinde, "İlk Kur'anî vahiy 19 kelimeden oluşmuştur"diyerek İkra suresinin ilk beş ayetini kelimelerine ayırmı̧ ve bunları 19 olarak çıkarmak için, "ellezî" ismi mevsulünü bir kelime olarak kabul ettiği halde "ma" ismi mevsulünü kendisinden sonra gelen "lem" edatıyla birlikte tek kelime halinde vermiştir." 4 nolu fiziksel gerçek! olarak ise, "Illk Kur'anî vahiy 76 harften oluşur ve 76 sayısı 19 un 4'le çarpımıdır” demektedir. Reşat, İkra suresinin bu ilk bölümünün

${ }^{85}$ Muhyiddin Hüseyin Nacî, Tisa'te a'şere meleken, Darü'z-Zehra li'l-A'lami'l-Arabî, 2.baskı, s. 127

A.g.c. s. 127

${ }^{87}$ Ibn Tcymiyyc, et-Tefsirü'l-kebir, 2/157.

${ }^{88}$ ez-Zerkanî, Menahilü'l-irfan, 2/334.

Bkz. Reşat halife, Edip Yüksel, Kur'an Görülen Mucize, Timaş a.ş. yay. İstanbul, 1985, s.23. 
harflerini 76 olarak çıkarmak için iki defa geçen "el-insan" kelimesindeki "elif"i saymayarak bu sayıyı tutturmaya çalışmıştır." 7 nolu fiziksel gerçekte! ise, "Illk sure olan İkra suresi 285 harften oluşmaktadır ve bu 19 sayısının 15 ile çarpımından teşekkül etmektedir" demektedir. Daha önce besmeleyi harflerine ayırırken "bismi" kelimesini üç harf olarak almış olduğu halde buradaki kurgusunu oluşturabilmek için aynı kelimeyi bu defa 4 harf olarak kabul etmektedir. Ancak bu da yeterli gelmemektedir. Reşat bunun için yine "el-insan" kelimelerindeki "elif"leri saymamakta ve "reâhu" kelimesinde -şimdiye kadar yaptığının aksine- "elif"in yanına bir de "hemze" ilave ederek sayısını 4'e çıkarmaktadır. Yine 7 nolu gerçekte! Peş peşe geçen "nâsiyetun" kelimesindeki "elif"i saydığı halde, "kâzibetun" kelimesinde ise saymamaktadır. ${ }^{9 !}$ Buna benzer misalleri çoğaltmak mümkündür. Ancak biz bu husus üzerinde daha fazla durmak istemiyoruz. Reşat'ın 19 rakamını üzerine oturttuğu kurgulama ve düştüğü teknik hatalar hakkında daha fazla bilgi almak isteyenler, Hüseyin Nacî Muhyiddin'in Tisa'te â'şere Meleken isimli kitabı ile Dr. Orhan Kuntman'ın Ondokuz Meselesinin Reddi ve Bu Mesele Ile Ilgili Önemli Açıklamalar ${ }^{92}$ konulu makalesine müracaat edebilirler. Her iki yazar, adı geçen incelemelerinde bu meseleyi çeşitli yönleriyle ele almış ve gerçekleri gözler önüne sermişlerdir.

\section{5. Sonuç}

Şimdiye kadar Kur'an i'cazıyla ilgili alimlerden varid olan görüşleri zikrettik ve bunları kategorilere ayırarak ortaya çıkan temel yönler hakkındaki değerlendirmelerimizi sırası geldikçe açıkladık. İncelememiz sırasında bu yönlerden bir çoğunun tehaddi mantığına uymadığını gördük. Bize göre bu hususta göz önünde bulundurulması gereken temel ölçü şudur: Kur'an, onun Allah katından gelen bir vahiy ürünü olmadığını iddia edenlere meydan okuyarak: "Eğer onun, Allah tarafından vahiy edilmiş bir kitap olduğunu kabul etmeyip, sizin gibi bir beşer olan Muhammed (as)tarafından ifade edildiğini iddia ediyorsanız, siz de birer insansınız, hatta sizin aranızda ondan çok daha bilgili olan insanlar vardır, buyurun siz de bir araya toplanın ve onun bir suresinin benzerini meydana getirin. Yok eğer bunu yapamıyorsanız - ki yapamazsınız- o halde bu iddianızdan vazgeçin." demiştir. Ayeti kerimede bu durum şu cümlelerle ifade edilmiştir:

"Ĕger kulumuza indirdiklerimizden herhangi bir şüphe içerisinde iseniz, haydi onun benzeri bir sure getirin, ĕger iddianızda doğru iseniz, Allah'tan başka şahitlerinizi (yardımcılarınızı)da çağırın. Bunu yapamazsanız -ki elbette yapamayacaksınız-yakıtt, insan ve taş olan cehennem ateşinden sakının.".93

\footnotetext{
${ }^{90}$ A.g.c. s. 24 .

${ }^{91}$ Bütün bunlar için bkz a.g.e. s. 29.

${ }^{92}$ Islamî Araşurmalar dergisi, c.2, sayı 7, Mayıs 1988.

${ }^{93}$ Bakara suresi: $23-24$.
} 
Ayette, Kur'an'ın her hangi bir suresinin benzerinin getirilmesi istenmiş ve bunun için herhangi bir sınırlama konulmamıştır. Dolayısıyla Kur'an'ın, kısa olsun uzun olsun bütün sureleri, bu tehaddi için geçerlidir. Yapılacak herhangi bir girişim bu surelerden herhangi birisinin özelliklerine uygun düşüyorsa bu cevap yeterli sayılabilir. Binaenaleyh, Kur'an'ın meydan okuduğu ve bir benzerini meydana getirmeye davet ettiği husus, bütün Kur'an surelerinde bulunan bir özellik olmalıdır. Bizim kanaatimizce bu özellik, Kur'an nassının metin yapısıyla alakalı bir husustur; o da Kur'an'ın sahip olduğu ifade tarzı, eski tabiriyle beyan üslûbudur. Bu üslub, barındırdığı üstün belağî özelliklerle insanı derin bir etki altında bırakarak, ilahî mesajın en güzel şekilde tebliğini sağlamıştır. Abdülkahir'in özellikle vurguladığı gibi $O$, harflerini, kelimelerini ve terkiplerini, istenilen mesajı en güzel anlatacak şekilde seçmiş, insanın ruhanî yapısını derinden etkileyecek bir tarzda vermek istediğini vermiş ve bu husus ta da son derece başarılı olmuştur. Bütün insanlar bir araya gelseler ve bütün imkanlarını seferber etseler, yine de onun bir benzerini, hatta küçük bir suresinin benzerini dahi meydana getiremezler. Zira insanı yaratan Allah'tır ve onun nelere ihtiyaç duyduğunu, neyi nasıl daha iyi anlayabileceğini en iyi bilen odur.

\section{KAYNAKÇA}

- Abbas, Fadl Hasan, el-Belağetu fununuha ve efnanuha(İlmü'l-meânî) Darü'lFurkan, 2.baskı, Amman, 1989. ,I'cazü'l-Kur'an, Amman, 1991.

-Aişe Abdurrahman, Bintu'ş-Şati', el-I'cazü'l-beyanî li'l-Kur'an, Darü'l-Meârif, Misir, 1971.

-Bediüzzaman Said Nursî, İşaratü'l-i'caz, trc.Abdülmecid Nursî, Envar Neşriyat, İstanbul, 1991.

-el-Bedrî, Ali, Hakaik ve ebatîl, Darü'l-Kitabi'l-Cahir, 1.baskı, 1982.

-el-Cürcânî, Abdülkahir, er-Risaletu's-şafiye (Selasu resail fi'l-i'caz içinde) thk. Ahmed Halefullah, Muhammed Zeğlul Selam, Darü'l-Mearif, Mısır, 1.baskı.

-el-Cürcânî, Ali b. Muhammed b. Ali, et-Ta'rifat, Darü'l-Kitabi'l-Arabi, 2.bask1, Beyrut, 1992.

-Draz Muhammed Abdullah, En Mühim Mesaj Kur'an (en-Nebeü'l-azîm) trc. Suat Yıldırım, Işık yay.İzmir, 1994.

-Ebû Zehra, Muhammed, el-Mu'cizetül-kubra: el-Kur'an, Darü'l-Fikri'l-Arabî, 1970.

- el-Fîyruzâbâdî, Muhammed b. Ya'kub, el-Kamusü'l-muhît, Müessesetu'r-Risale, 2.baskı, 1987.

- el-Hafacî, İbn Sinan Sirrü'l-fesahe, thk. Ali Fevde, l.baskı, Mektebetü'l-Hancî, 1932.

-Halife, Reşat, Edip Yüksel, Kur'an Görülen Mucize, Timaş a.ş. yayını. İstanbul, 1985.

-el-Hattabî, Ebû Süleyman Hamd b. Muhammed, Beyanü i'cazi'l-Kur'an, (Selasu resail fi'l-i'caz içinde) thk. Ahmed Halefullah, Muhammed Zeğlul Selam, Darï'l-Mearif, Mısır, 1 baskı. 
-İbn Manzur, Lisanü'l-Arab, Beyrut, 1956.

-İbn Teymiyye, Takıyuddin Ahmed, et-Tefsirül-kebir, derleme ve thk. Abdurrahman Umayra, Darü'l-Kütübi'l-İlmiyye, Beyrut. trh

-el-İmarî, Ali, Havle i'cazi'l-Kur'an, Silsiletu's-sekafeti'l-Islamiyye, Kahire, 1962.

- el-Isfahanî, Rağıb, el-Müfredat, thk. M. Ahmed Halefullah, Mektebetu Anclo elMisriyye, trh.

- Islamî Araştırmalar dergisi, c.2, sayı:7, Mayıs 1988.

-Kurtubî, el-Cami' li ahkami' '-Kur'an, Müessesetu Menahili'l-Kur'an baskısı

-Mahlûf, Abdürrauf, el-Bakıllânî ve kitabühü i'cazü'l-Kur'an, Daru Mektebeti'lHayat, Beyrut, 1973.

-Menna' el-Kattan, Mebahis fí ulumi 'l-Kur'an, Muessesetu'r-Risale, Beyrut, trh,

-el-Mu'cemü'l-vasit, Çağrı yay. İstanbul, 1992.

-Muhammed İsmail, İbrahim, el-Kur'an ve i'cazühü't-teşrî̀, Darü'l-Fikri'l-Arabî baskısı.

-Muhyiddin, Hüseyin Nacî, Tisa'te â'şere meleken, Daru'z-Zehra li'l-A'lami'lArabî, 2.baskı.

-er-Rafîi, Mustafa Sadık, I'cazü'l-Kur'an ve'l-belağetu'n-nebeviyye, Darü'lKitabi'l-Arabî, Beyrut, 1990

-er-Razî, Fahreddin, et-Tefsirü'l-kebîr, Daru İhyai't-Turasi'l-Arabî ,3.bask1.

-er-Rummânî Ebư'l-Hasan Ali b. İsa, en-Nüket fí i'cazi'l-Kur'an (Selasu resail fíl$i^{\prime} c a z$ içinde) thk. Ahmed Halefullah, Muhammed Zeğlul Selam, Darü'l-Mearif, Misır, 1 .baskı.

-eş-Şatıbî, Ebû İshak, el-Muvafekât fí usûli'ş-Şerîa, şrh. Muhammed Abdullah Draz, Matbaatu'ş-Şarki'l-Ednâ.

- Ünlü, Demirhan, Kur'an-ı Kerim'in Tecvidi, Şamil yay. Ankara, trh.

-ez-Zebîdî Muhammed Murtedâ, Tacü'l-ârus, Kuveyt, 1975.

-ez-Zemlekânî, el-Burhanü' l-kâşif a 'n i'cazi'l-Kur'an, Matbaatü'l-Âni, Bağdat, trh.

-ez-Zerkanî, Muhammed Abdülazim, Menahilü'l-irfan fí ulumi'l-Kur'an, Darü'lFikr, 2.baskı, trh.

-ez-Zerkeşî, Muhammed b. Abdullah, el-Burhan fi ulumi'l-Kur'an, Darü'l-Fikr, 1.baskı, 1988. 